\title{
Action Learning in the neighbourhood of Benicalap (Valencia): an innovative teaching and learning experience in an International Development Master
}

\author{
Pellicer-Sifres, Victoria ${ }^{a}$; Boni, Alejandra ${ }^{a}$; Leivas Vargas, Monique ${ }^{a}$; Wassel Antich, \\ Vania $^{b}$ \\ ${ }^{\mathrm{a}}$ Ingenio (CSIC - UPV), Universitat Politècnica de València, Spain, ${ }^{\mathrm{b}}$ Independent \\ Consultant
}

\begin{abstract}
This article aims to analyze an innovative teaching and learning experience carried out by the "Development Cooperation Master's Degree" taught at the Politechnical University of València (UPV), Spain. During two weeks, the students of the Master carried out an Action Learning process in the neighborhood of Benicalap (Valencia), with the aim to explore how the housing conditions in the neighborhood influence on the youth's learning and aspirations. The process was developed with the participation of three local organization. As outputs of this research, some proposals for improving the neighbourhood were presented to several actors from Benicalap. University exercised then a part of its social responsibility, moving lessons from the classroom to the street. In turn, UPV students acquired social and technical skills for their personal and professional development.
\end{abstract}

Keywords: Action Learning, Devlopment, Cooperation, Learning, Youth's aspirations 


\section{Introduction}

This article aims to analyze an innovative teaching and learning experience carried out by the "Development Cooperation Master's Degree" (Master Universitario en Cooperación al Desarrollo -from here, the Master-) taught at the Politechnical University of València (UPV), Spain.

During two weeks (from the $29^{\text {th }}$ of May 2017 to the $9^{\text {th }}$ of June 2017), the students of the Master carried out an Action Learning process in the neighborhood of Benicalap (Valencia), with the aim to explore how the housing conditions in the neighborhood influence on the youth's learning and aspirations. The process was developed with the participation of three local organisations: "Ultramarins 154" (a cultural, playful and gastronomic association); "Casa Caridad" (a non-profit charity association) and the Benicalap Institute of secondary education (from here, IES Benicalap).

\subsection{The Development Cooperation Master's Degree}

The Development Cooperation Master's Degree of the UPV is intended to contribute towards the training of development professionals who may in turn act as agents for change in the different places and contexts where they operate. As agents for change, these professionals ought to develop qualities such as the ability to understand and practice citizen participation, the need to have a global approach and knowledge, and attitudes which allow them to position themselves in a critical but also transforming standpoint in the area of development in general, and of international development cooperation in particular (Boni et al, 2016).

Therefore, during the planning of their educational itinerary (the Master's programme) alternative methodologies that develop and implement these capabilities are strongly considered and included. Because of that, the methodology of "Action Learning" (hereinafter AL) was incorporated, since it was considered that learning processes outside the classrooms, embedded in a context with real and close problems, are more likely to contribute to to the development of this critical and reflexive practice.

\subsection{Action Learning, as an innovative methodology for critical learning}

$\mathrm{AL}$ is defined as a learning process that is applicable to situations where participants face complex problems and learn by exploring new opportunities, instead of applying the routines of pre-established systems (Pedler and Burgoyne, 2008). This type of learning also has an ethical dimension (De Carli and Kinnear, 2015), whereby the experiences of the participants are part of a wide range of activities that can contribute positively to the initiatives of the local organizations participating in the AL. The contribution can be in the form of generating products (such as research reports) or initiating processes (eg dialogue 
and mobilization) that are relevant to the needs and aspirations of the participating organizations.

\subsection{Benicalap and the three local organisations involved in the $A L$}

Currently, in Benicalap there is a high rate of families in risk of social exclusion: according to the Valencia City Council study on vulnerable areas (2016), 27.7\% of the population of Benicalap is considered living in a vulnerable situation. The great majority of the population work in sectors that need low qualification. The social fabric (social organisations, associations, etc) is weak and disconnected from youth people. The historical and cultural heritage of the neighborhood is neglected by the public administration and there are quite a lot of abandoned lots.

From the above explained, we can easily deduct that the fact of including the point of view of the organisations from Benicalap is an essential requirement to be able to identify, understand and analyze the problems, as well as to be able to elaborate realistic and relevant action proposals. In our experience, three organizations from the Benicalap neighborhood participated: Ultramarins 154 (they collaborated by making available all his infrastructure for the realization of the different activities), Casa Caridad (they participated on the AL through their Nursary School) and IES Benicalap (they get involved on the AL through three classrooms).

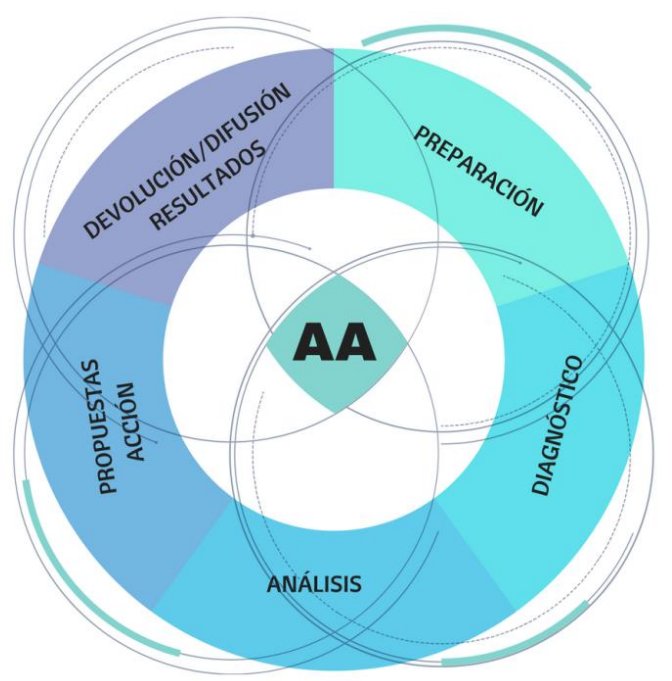

Figure 1. Phases of Action Learning process 


\section{Methodology: the process of $\mathrm{AL}$ in Benicalap}

The AL process was planned based on five main phases that took place during the fifteen days of the investigation: 1) Preparation; 2) Diagnosis; 3) Analysis; 4) Proposals for action and 5) Return / dissemination of results. In Figure 1, they are represented graphically.

\section{Phase 1: Preparation}

In this phase (days 1-2), the group became familiar with the neighborhood and with the actors with whom each group would work. A first tour of the neighborhood was made to know its reference places (transect technique) and the representatives of the different organizations met. The theoretical elements that would guide the investigation and the work agenda were presented.

\section{Phase 2: Diagnosis}

In this phase (days 2-7) the classroom was divided in 4 groups, in orther to gather the information to answer the research questions about "how the housing conditions in the neighborhood influence on the youth's learning and aspirations?". The techniques used for this were:

- Questionnaires

- Participatory workshops

- Personal narratives

- Semi-structured interviews

- Participant observation

- Since the context of each group varied from one group to another, that meant that not all the groups used the same research techniques. For more detail, see Table 1 
Table 1.

\begin{tabular}{|c|c|c|c|c|}
\hline Técnica & G1 & G2 & G3 & G4 \\
\hline Initial tour & collective tour & 5 tours & $\begin{array}{c}1 \text { collective } \\
\text { tour }\end{array}$ & $\begin{array}{c}1 \text { collective } \\
\text { tour }\end{array}$ \\
\hline Questionnaires & $\begin{array}{c}1 \text { initial Q. } \\
1 \text { final Q. }\end{array}$ & --- & $21 \mathrm{Q}$. & $70 \mathrm{Q}$. \\
\hline $\begin{array}{l}\text { Participatory } \\
\text { workshops }\end{array}$ & --- & --- & $1 \mathrm{WP}$ & $9 \mathrm{WP}$ \\
\hline Personal narrati & --- & --- & --- & 8 Narratives \\
\hline $\begin{array}{l}\text { Semi-structured } \\
\text { interviews }\end{array}$ & 25 & 12 & 9 & 4 \\
\hline $\begin{array}{l}\text { Participant } \\
\text { observation }\end{array}$ & During all process & $\begin{array}{l}\text { During all } \\
\text { process }\end{array}$ & $\begin{array}{l}\text { During all } \\
\text { process }\end{array}$ & $\begin{array}{c}\text { During all } \\
\text { process }\end{array}$ \\
\hline
\end{tabular}

Figure 1. Research techiniques during diagnosis phase

\section{Phase 3: Analysis}

In this phase (days 6-11) the information collected was analyzed and the results of the research were obtained. Throughout this phase, spaces were planned to share the preliminary and final findings with the rest of the groups.

\section{Phase 4: Proposals for Action}

This phase (days 8-12) was worked in parallel with the former phase. The preliminary findings allowed to obtain first ideas of proposals for action, which were discussed and complemented with the organizations.

\section{Phase 5: Return and dissemination of results}

In this phase (days 13-15) the dissemination materials of the project results were prepared: 2 posters explaining the process and 3 posters that synthesized the results. In addition, a video summary of the experience was prepared. 


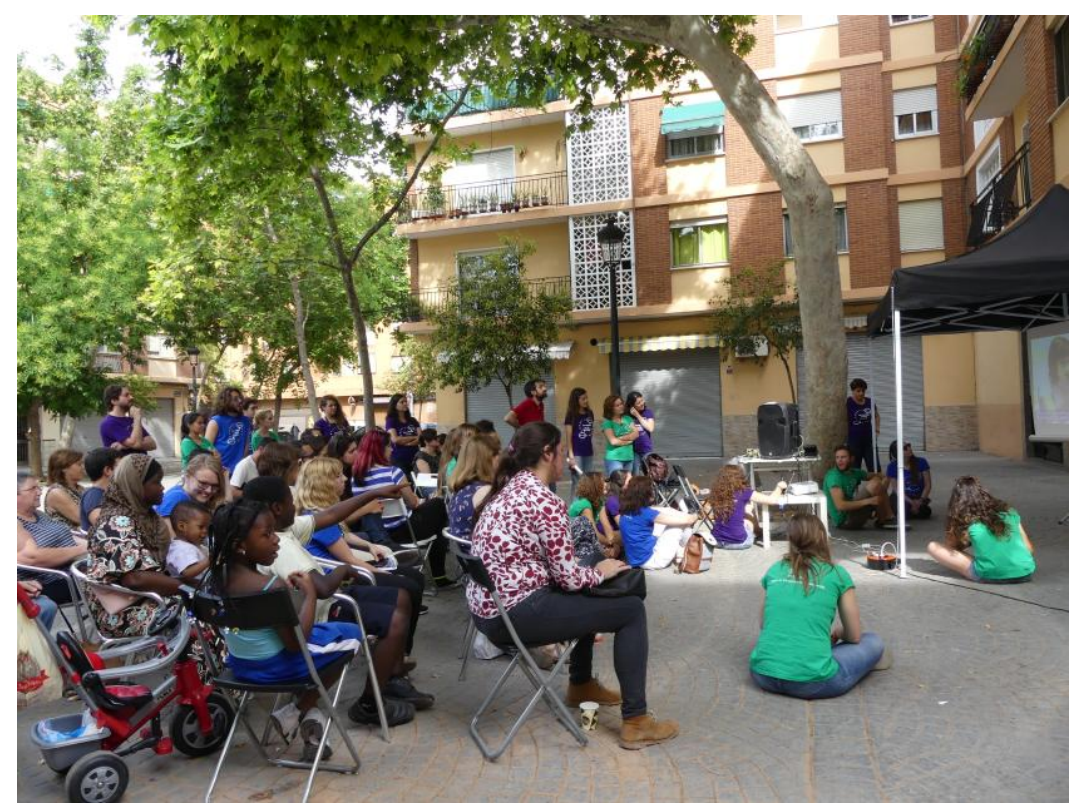

Image 1.Public presentation and space of debate with neighbors from Benicalap

The final day of the AL process ended with a public presentation of the results. In the square of the neighborhood, the 5 posters were exhibited, the video was presented and a dialogue space was created between the participants of the process and the neighbors from Benicalap. This was a key moment to share learnings and impressions, as well as to reflect on how the AL process could be contributing to improving the welfare of the young people of Benicalap.

\section{Learnings and conclusions}

In this section, we briefly present main reflections and conclusions about learnings adquired during the AL process:

Regarding public space in Benicalap:

All the groups involved during the AL process coincide in stating that the public resources available to the Benicalap neighborhood are insufficient and that they are not aligned with young people interests or with families' assisting to Casa Caridad needs.

\section{Regarding housing conditions}

Also in this issue, a greater public investment seems necessary to improve the conditions of the Institute (there were not thermal confort inside the classrooms) and the public transport 
network to Benicalap (evidences found difficulties for arriving to Casa Caridad using public or economic transport).

\section{Regarding Learning Aspirations}

People interviewed during the process consider the capability of learning as an instrument to find a job, or to have economic stability. During the AL intervies, values as justice, common good, participation, collectivity or sustainability were quite absent. Master students reflections suggested that it was a consequence of a societal model built upon mindsets such as individualism, consumption, money as an indicator of personal success, etc. They highlighted the importance of promoting activism initiatives in order to engage young people and contribute to foster their critical point of view and their participation and implication in society.

\section{Regarding network among different actors}

The AL conclusions highlighted the importance of connecting public and private Benicalap organizations, such as Ultramarins 154, the Benicalap IES, Casa Caridad, etc. The strenghten of networks between these organizations would be very relevant for two main objectives:

- To collectively reclaim public investment in infrastructure for leisure and youth participation.

- To generate solid alliances and promote actions in order to involved young people

\section{The AL, as a process to adquire relevant learning for development practitioners}

During the evaluation of this initiative, the Master's students considered that it has been a process where they have learnt relevant issues for their professional career as a development practioners. Among all learning adquired, they highlighted the following four issues as the most important learning, and they emphasized the fact that these learnings couldn't have been adquired through a classical learning methodology "inside the classroom":

- Collective learning, which means learning that couldn't be adquired without being embedded in a group (active listening, work in groups, emphaty, conflict resolution, etc...)

- $\quad$ Learning about facilitation skills

- Awarness about the relevance of informal spaces for learning and dialogue

Our final conclusion is that this AL initiative has really contributed to the learning of the students of the master's degree, and that undoubtedly this learning has been more complex and deeper due to the fact that it has been obtained through the practice itself. 


\section{References}

Boni A., Calabuig C. and Pellicer-Sifres V. (2016) "Transforming the system from within: the experience of the Development Cooperation Master of the Universitat Politènica de València" in Socially Just Pedagogies, Capabilities and Quality in Higher Education (In press). Palgrave Macmillan.

De Carli, B. y Kinnear, M. (2015) Learning amidst urban practices: reflections on Architecture Sans Frontières, Charrette 2(1), pp. 46-56.

Oficina d'Estadística de l'Ajuntament de València (2016): Àrees vulnerables a la ciutat de València. Valencia. Disponible en:

http://www.valencia.es/ayuntamiento/webs/estadistica/CatPub/files/Arees\%20Vulnerabl es.pdf [Accesado el 01 de junio de 2017]

Pedler, M. y Burgoyne, J.G. (2000) Handbook of Action Research: Participative Inquiry and Practice. London: Sage. 